\title{
Pembentukan Identitas Sosial Komunitas Hadhrami di Batavia Abad XVIII-XX
}

\author{
AHMAD ATHOILLAH \\ Mahasiswa Program Studi IImu-IImu Humaniora FIB UGM \\ Email: athoilahmadgkp@gmail.com
}

\begin{abstract}
This paper discusses the process of forming identities carried out by the Hadhrami community in Batavia throughout the late 18th century until the beginning of the 20th century. The taking of the topic was motivated by the strong social identity of the Hadhrami community in Batavia, especially in religion and economy since the 19th century to the present. The problem of this research is about the form and process of forming Hadhrami social identity from the end of the 18th century to the beginning of the 20th century. To answer these problems, a critical historical method is used by using various historical sources and relevant reference studies.

Some of the results obtained from this study are various historical realities, such as the formation of social religious symbols including mosques and religious teaching forum. Some important things are the formation of economic identities such as wholesale trade, shipping businesses and property businesses. In addition, there were also shifting settlements from Hadhrami over the Koja people in Pekojan in the early 19th century, as well as the shift of the Hadhrami to the inland of Batavia in the late 19th century. These various realities ultimately affected various forms and processes of forming the social identity of the Hadhrami community, such as the material aspects, language, behavior, and collective ideas of the Hadhrami community especially at the beginning of the 19th century. Generally the Hadhrami community had transformed themselves and their collective parts into colonial society in Batavia until the beginning of the 20th century.
\end{abstract}

\begin{abstract}
Abstrak
Makalah ini membahas tentang proses pembentukan identitas yang dilakukan komunitas Hadhrami di Batavia sepanjang akhir abad ke-18 hingga awal abad ke-20. Pengambilan topik tersebut dilatarbelakangi oleh kentalnya identitas sosial komunitas Hadhrami di Batavia terutama pada bidang keagamaan dan perekonomian sejak abad ke-19 sampai saat ini. Permasalahan penelitian ini adalah tentang bentuk dan proses pembentukan identitas sosial Hadhrami sejak akhir abad ke-18 sampai awal abad ke20. Untuk menjawab permasalahan tersebut, maka dipakai metode sejarah yang kritis dengan menggunakan berbagai sumber sejarah dan telaah referensi yang relevan. Beberapa hasil yang diperoleh dari penelitian ini adalah bahwa terdapat berbagai realitas sejarah, seperti pembentukan simbolitas sosial keagamaan seperti masjid
\end{abstract}

\section{Keywords:}

social identity; Hadrami community; Batavia

Kata Kunci: identitas sosial; Komunitas Hadhrami; Batavia 
dan majelis pengajaran keagamaan. Beberapa hal penting adalah pembentukan pada identitas perekonomian seperti perdagangan grosir, usaha pelayaran dan usaha properti. Selain itu juga ditemukan adanya peristiwa pergeseran pemukiman baik dari Hadhrami atas orang Koja di Pekojan pada awal abad ke-19, maupun pergeseran orang Hadhrami ke daerah pedalaman Batavia pada akhir abad ke-19. Berbagai realitas tersebut pada akhirnya berpengaruh terhadap berbagai bentuk dan proses pembentukan identitas sosial komunitas Hadhrami, seperti pada aspek material, bahasa, perilaku, dan gagasan kolektif pada komunitas Hadhrami khususnya pada awal abad ke-19. Secara umum komunitas Hadhrami telah mentransformasi diri dan kolektif mereka menjadi bagian dari masyarakat kolonial di Batavia sampai dengan awal abad ke-20.

\section{Pendahuluan}

Sebagai pusat perdagangan terbesar VOC di kawasan Samudera India dan Pasifik, Batavia merupakan tujuan para imigran baik dari kawasan kepulauan Nusantara dan daerah-daerah di kawasan Asia. Aktifitas perekonomian dan perdagangan kolonial menjadikan Batavia kemudian tumbuh menjadi kota kolonial yang tersusun dari berbagai perkampungan etnis (Kuntowijoyo, 2003: 53). Sebuah sensus penduduk di dalam dinding kota Batavia pada tahun 1673 menunjukan nama-nama etnis tersebut di antaranya, seperti etnis Belanda, Eurasia, Cina, Moor, Jawa, Melayu, Sunda, Bali, dan budak. Istilah Moor oleh Blackburn (2011: 28,44) juga sering disebut sebagai “Koja”, dalam kajian ini lebih diartikan sebagai etnis muslim dari Suraj, India. Makalah ini secara khusus akan melihat berbagai usaha pembentukan identitas sosial yang dilakukan oleh komunitas Hadhrami di Batavia. Definisi tentang "identitas" menjadi suatu dasar yang penting untuk melihat pembentukan identitas kaum Hadhrami. Menurut Ahimsa-Putra (2013), identitas atau jati diri adalah kumpulan simbol atau tanda (baik fisik, material maupun perilaku) yang membuat seorang individu atau sekumpulan individu terlihat berbeda dengan individu atau sekelompok individu yang lain dengan berbagai macam skala dan bentuk. ${ }^{1}$ Implikasinya adalah bahwa simbol atau tanda (fisik, material dan perilaku) yang biasa disebut identitas menjadi penting untuk membedakan antara satu dengan yang lain. Dalam sebuah kelompok atau komunitas, simbol ${ }^{2}$ lebih diartikan sebagai proses sosialisasi dari sebuah komunitas yang membentuk bagian keanekaragaman budaya di Batavia sepanjang

1) Ahimsa-Putra mengutip pendekatan W. Goodenough, sementara komunitas lebih dilihat sebagai skala dan bentuk masyarakat yang berarti sebuah kumpulan dari individu, keluarga inti maupun golongan tertentu (Ahimsa-Putra, 2013: 11).

2) Simbol diartikan segala sesuatu yang dimaknai, Ahimsa-Putra (2013:8-9) juga menyatakan bahwa simbol dapat berupa: (1) hal-hal yang abstrak, (2) hal-hal yang agak abstrak, (3) hal-hal yang sangat konkret dan empiris. Sedangkan aspek kebudayaan meliputi (aspek fisik/budaya meterial; aspek perilaku/budaya perilaku; aspek kebahasan atau bahasa dan aspek gagasan/budaya pengetahuan). Menurut Ahimsa-Putra sebuah kebudayaan memiliki 10 unsur diantaranya unsur keagamaan, klasifikasi, komunikasi, permainan, pelestarian, organisasi, ekonomi, kesenian dan transportasi. 
abad ke-18 sampai dengan abad ke-20. Dengan pendekatan konsep identitas di atas maka permasalah utama seperti bentuk identitas sosial komunitas Hadhrami dalam ruang sosial perkotaan di Batavia akan diketahui. Selain itu, pembentukan identitas sosial komunitas Hadhrami juga akan dilihat dengan kerangka pendekatan gejala sosial perkotaan yang khas seperti ekologi sosial, transformasi sosial, sistem sosial, permasalahan sosial, dan mobilitas sosial (Kuntowijoyo, 2003: 64). Dari definisi dan pendekatan di atas, maka rumusan masalah yang perlu dijawab adalah pertama, bagaimanakah komunitas Hadhrami melakukan pembentukan identitas sosial di Pekojan pada akhir abad ke-18 dan awal abad ke-19? kedua, sejauh mana komunitas Hadhrami melakukan sosialisasinya terutama ketika mereka bergeser dari Pekojan ke wilayah pedalaman Jakarta paruh kedua abad ke 19? ketiga, bagaimanakah bentuk identitas sosial baru komunitas Hadhrami di Batavia pada awal abad ke-20?

\section{Komunitas Hadhrami dan Batavia pada Akhir Abad ke-18 Asal usul kaum Hadhrami}

Hadhrami atau "Arab Hadhrami” adalah sebutan bagi penduduk asli Hadhramaut yang tinggal di wilayah Hadhramaut, Yaman Selatan. Mereka terdiri dari penduduk asli (ras 'Aribah atau Arab selatan) keturunan Ya'rab bin Qathan dan penduduk keturunan pendatang dari Basrah (ras Muta'aribah atau Arab utara) yaitu Ahmad bin Isa al- Muhajir. ${ }^{3}$ Secara geografis, Berg (1989: 7) menyebutkan bahwa Hadhramaut adalah wilayah pantai Arab selatan dari Aden sampai Tanjung Ras al-Hadd yang dihiasi dengan pegunungan gersang, sedikit padang rumput (mar'ah), hutan pohon sibr, dan pohon berduri. ${ }^{4}$ Masyarakat Hadhrami sesuai tradisinya terbentuk dari empat golongan diantaranya adalah: (1) golongan sayid, (2) anggota suku atau "syekh", (3) golongan menengah seperti pedagang, dan (4) golongan budak. Golongan sayid (keturunan Nabi Muhammad) merupakan kelompok elit keagamaan yang terbagi dari berbagai keluarga (qabilah) yang masing-masing dipimpin oleh seorang munsib. ${ }^{5}$ Sementara untuk jabatan kepala suku disebut dengan istilah muqaddam. Kekuasaan di Hadhramaut dipegang oleh para sayid yang mempertahankan hukum Islam dan seorang penguasa daerah (muqaddam) dengan para hakimnya (qadi). Untuk penduduk golongan menengah di Hadhramaut pada umumnya berprofesi menjadi pedagang, pengrajin, petani,

3) Ahmad bin isa Al-Muhajir adalah seorang keturunan Nabi Muhammad SAW yang datang dari Basrah (Irak) ke Hadhramaut pada tahun 927. Para keturunan Al-Muhajir tersebut di Hadhramaut dikenal dengan istilah kelompok sayid (Ba'Alawi) (Berg, 1989: 7; Ibrahim, 2011: xxii, 18).

4) Pohon berduri disebut sebagai pohon Salam dan is dan pohon Musyt (sejenis pohon Akasia).

5) Munsibjuga dianggap sebagai pemimpin agama oleh suku-suku di Hadramaut dan sebagai penguasa daerah bagi tempat tinggalnya (Berg, 1989: 24, 26,30,31). 
dan pembantu. Sebelum abad ke-20, Hadhramaut tidak memiliki pemerintah resmi, kecuali menerima "protektorat" kekuasaaan gerbang suci Ottoman dalam mengantisipasi konflik antar suku tanpa ada bentuk aliansi politis yang resmi antara Hadramaut dengan Turki. Bidang pendidikan lebih terlihat mendominasi aktivitas masyarakat Hadhramaut dibandingkan bidangbidang kehidupan lainnya. Sementara untuk masalah keamanan wilayah di Hadhramaut secara khusus ditangani oleh polisi dan tentara yang dibentuk oleh praksarsa pribadi para kepala suku. Keadaan geografis yang kurang menguntungkan untuk pertanian dan perdagangan maupun situasi politik yang tidak menentu pada sepanjang abad ke-18 dan 19 telah mendorong penduduk Hadhrami melakukan migrasi keluar dari Hadramaut (Alatas, 2000: xxxi, xxxvii).

\section{Pekojan: Dominasi Kaum Hadhrami atas Bangsa Koja (Moor)}

Kampung Pekojan ${ }^{6}$ terletak di pinggir kali Angke sebagai kampung yang ditempati oleh orang Koja dan keturunannya. Mereka adalah imigran muslim dari Gujarat dan Suraj di India Barat yang sudah ada di Batavia sejak abad ke17. Pemukiman Koja tersebut secara geografis berada di pantai utara Batavia, tepatnya terletak di antara Jalan Bandengan selatan (Ammanusgracht) dan Jalan Pekojan (Bacherachtgracht).

Orang Koja ${ }^{7}$ sejak tahun 1648 telah membangun sebuagh masjid yang sekarang disebut sebagai masjid Al-Ansor dan juga mendirikan Langgar Tinggi di Jalan Pekojan. Pada paruh kedua abad ke-18, kehadiran imigran Hadhrami telah terlihat perannya di Batavia melalui peran perdagangan dan keagamaan. Pada umumnya mereka juga tinggal di pemukiman etnis Koja di Pekojan. Pada pertengahan abad ke-18, jumlah dan sosialisasi imigran Hadhrami telah terlihat di Pekojan. Hal itu terlihat ketika tokoh Hadhrami bernama Sayid Abdullah bin Husain Alaydrus membangun masjid Pekojan (sekarang disebut an-Nawir) pada tahun 1750 (Jonge, 2000: 144-5). Masjid ini sampai awal abad ke-20 tetap menjadi simbol utama keagamaan bagi komunitas Hadhrami yang paling penting di Batavia. Sejak saat itu, secara perlahan jumlah populasi Hadhrami di Pekojan semakin bertambah, walaupun masih terdapat sebagian kecil orang-orang Koja dan Tionghoa. Pada tahun 1812-1813, status orang “Arab Hadhrami” masih disatukan dengan orang Koja dalam catatan jumlah penduduk di Batavia. Raffles melaporkan bahwa pada periode tahun 1812-1813 masih terdapat 423 orang. ${ }^{8}$

6) Menurut Abdul Aziz yang mengutip pendapat S.C Misra, komunitas muslim yang di Gujarat ada dua diantaranya komunitas Khojah dan Bohra. Pekojan (Pakojan) diambil dari istilah komunitas Khojah ( Aziz, 2002: 13).

7) Istilah Moor juga diterapkan untuk para imigran muslim yang datang dari Pantai Koromandel dan Malabar (Jonge, 2000:143-144).

8) Pada lembaran halaman 63 dalam buku History of Java, Raffles membagi Jakarta dengan jumlah orang Moor adalah menjadi Batavian and Preangen Regencies (-), Environs Batavia (23 orang) dan City of Batavia (403) (Raffles, 1817:63). 
Dalam catatan jumlah penduduk tahun 1859 untuk Arab Hadhrami dan Koja telah dipisah, walaupun jumlahnya keduanya masih dijadikan satu yaitu 312 orang di Batavia. Dalam catatan Blackburn (2011: 87) disebutkan bahwa kehadiran komunitas Arab Hadhrami di Batavia tidak lebih dari jumlah ratusan, namun berhasil menujukan perang agama yang khas dan menggantikan orang-orang Koja yang memilih keluar dari Pekojan sejak awal abad ke-19. Menurunnya jumlah orang Koja tersebut disebabkan karena terhentinya hubungan perdagangan mereka dengan India, ketika daerah tersebut ditakhlukan oleh Inggris.

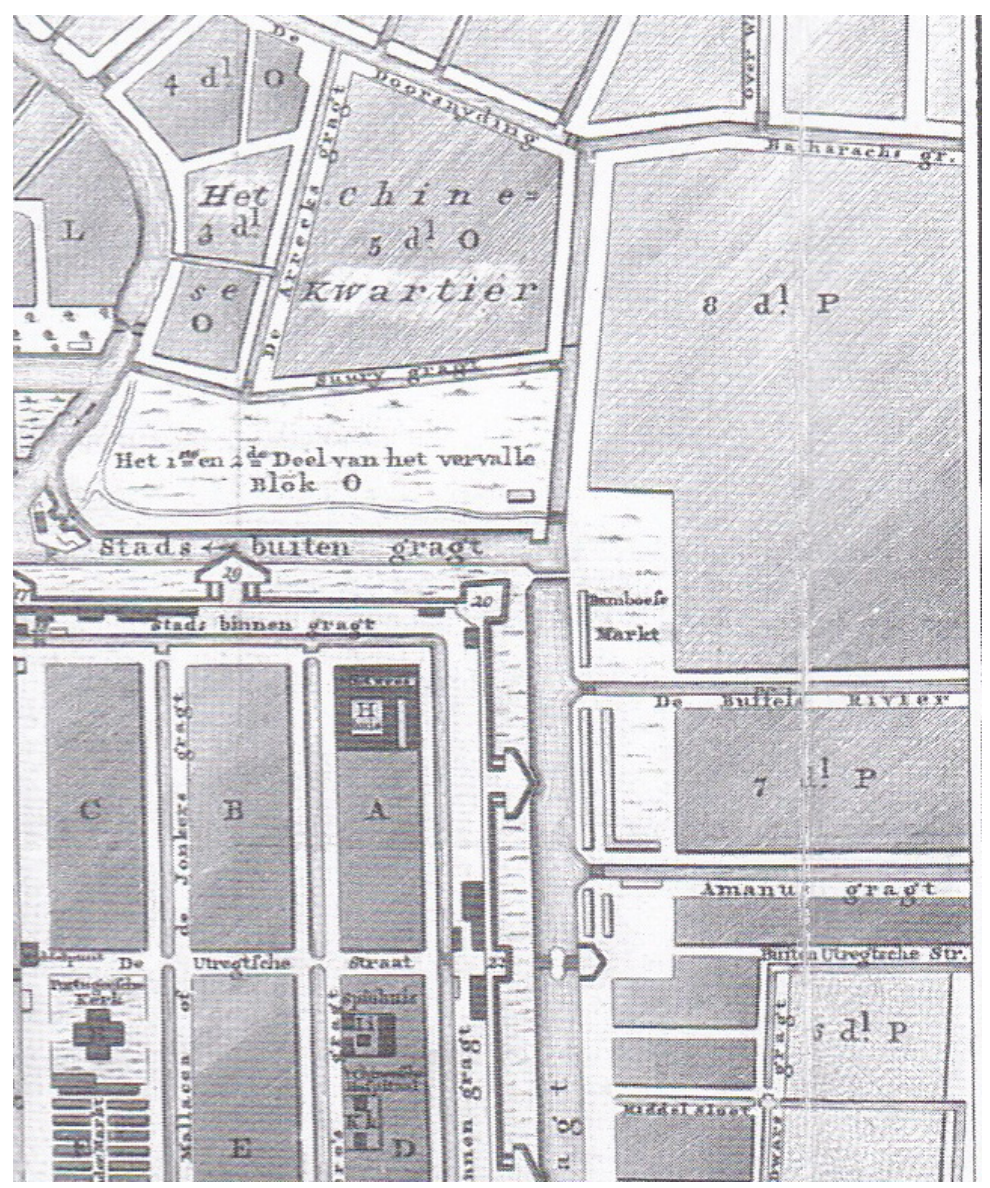

Figur 1. Letak Kampung Pekojan di antara Jalan Bandengan selatan (Ammanusgracht) dan Jalan Pekojan (Bacherachtgracht). Sumber: Blackburn, 2011.

Walaupun demikian, masih

terdapat orang-orang Koja yang berdagang kain sutra di Pasar Baru dekat Weltevreden sampai pertengahan abad ke-19.

Sampai akhir abad ke-19, Kampung Pekojan telah dihuni oleh sebagian besar imigran baru Hadhrami dan keturunan Hadhrami. Oleh karennaya, maka masyarakat Batavia sering menyebut kampung Pekojan dengan istilah "Kampung Arab" atau kampung yang ditempati oleh orang Arab. tidak hanya kampung saja, masyarakat Batavia juga tetap mengingat ketokohan Hadhrami seperti Sayid Abdullah bin Husain Alaydrus dengan sebuah nama jalan yang dsiebut sebagai Jalan Alaydrus atau Alaydrus Laan. ${ }^{9}$ Dalam perkembanganya pada akhir abad ke-19, Berg mencatat bahwa imigran Hadhrami telah berkumpul di Pekojan dan membentuk sebuah koloni besar di Batavia. Sampai akhir abad ke-19, Berg (1989: 72) juga menyebutkan bahwa koloni Arab di Batavia merupakan salah satu dari enam koloni besar Hadhrami di di Jawa.

9) Jalan Alaydrus dikenal sebagai "Alaydrus Laan” atau sebuah jalan besar masuk ke kota yang sekarang bisa ditemui di Jalan Gadjah Mada. Dahulu Alaydrus Laan ini merupakan kediaman dari Sayid Abdulah bin Husain Alaydrus, pendiri masjid An-Nawir Pekojan pada tahun 1750 (Shahab, $2006: 37$ ) 
Pada periode akhir abad ke-18 sampai akhir abad ke-19 dapat dikatakan bahwa komunitas Hadhrami berisi imigran awal dan anak-anak mereka atau yang disebut sebagai "generasi awal". Untuk mereka yang lahir di Hadhramaut dan kemudian tinggal di Batavia disebut sebagai Arab asli (wulaiti), sementara untuk generasi keda dari mereka disebut Arab peranakan atau campuran (muwallad $)^{10}$. Dalam ciri khas personalnya, mereka masih identik terlihat sebagai "orang Arab" yang terlihat dari ciri dan bentuk tubuh, gaya bicara, dan pakaian serta bahasa ${ }^{11}$ mereka. Beberapa hal yang berubah secara material sampai pertengahan abad ke-19 adalah bentuk bangunan rumah orang Hadharami yang tidak lagi bercorak Arab seperti di Hadhramaut, namun lebih pada rumah tembok yang bergaya kolonial. Dalam hal perilaku, komunitas Hadhrami di Pekojan melakukan sosialisasi seperti melakukan aktifitas perdagangan dan pengajaran keagamaan. Mereka juga terlihat melakukan aktifitas sehari-hari seperti di pasar, maupun mandi, mencuci pakaian, dan mengambil air di Kali Angke (Blackburn, 2012: 44-45, 141).

\section{Identitas dan Gejala Sosial Perkotaan Batavia}

Sebagai kota yang heterogen dan multikultur, Batavia memiliki berbagai etnis yang masing-masing mempunyai identitas sosial yang berbeda. Dalam pasal 163 Indische Staatsregeling, komunitas Hadhrami dicatat -sebagai Arab- yang masuk dalam golongan Vreemde Oosterlingen (timur asing) bersama etnis Tionghoa dan India (Algadri, 1996: 42). Ismail Fajrie Alatas menerangkan bahwa identifikasi "Arab" atas etnis Hadhrami muncul sebagai sebuah stereotype dari pemerintah kolonial, dimana konteks "Arab dan etnisitas" dirubah dari konstruksi identitas primordial dirubah menjadi identitas non-primordial (Berg,2000: xxiv). Oleh karenanya, sejak akhir abad ke-19 Kampung Pekojan lebih identik disebut sebagai “kampung Arab”, walaupun nama kampung tersebut tetap bernama Pekojan. Hal tersebut menunjukkan bahwa sebutan "kampung Arab" yang disebut oleh masyarakat Batavia hanya merupakan simbol baru yang dimaknai "menjadi sebuah kampung yang ditempati oleh orang-orang Arab”. Selain itu, istilah -Arab- dalam perspektif identitas yang juga diberikan oleh pemerintah kolonial telah menjadi simbol untuk sebuah identitas pembeda dengan nama kelompok lainnya. Walaupun pemerintah telah mengidentitaskan kaum Hadhrami sebagai "Arab", mereka juga membentuk identitas sosial tersendiri untuk menjadi bagian keanekaragaman budaya di Batavia yang terbentuk oleh proses sosialisasi yang

10) Wualiti adalah orang Hadhrami yang lahir di Arab, sedangkan Muwalad adalah mereka yang lahir di Hindia Belanda dengan ayah Hadhrami dan ibu dari perempuan pribumi (negeri baru para imigran Hadhrami) (Mobini-Kesheh, 1996: 242).

11) Pada generasi awal, komunitas Hadhrami masih berkomunikasi dengan bahasa Arab, walaupun secara fisik jelas mereka berbeda dengan pribumi, Cina dan Eropa ataupun etnis Nusantara, mungkin persamaanya lebih mendekati dengan bangsa Eurasia (Berg, 1989:72-73, 121). 
meliputi pembelajaran nilai-nilai, pandangan hidup kelompok, komunitas atau masyarakat tempat seseorang dibesarkan (Ahimsa-Putra,2013: 8).

Bagian terbesar dalam komunitas Hadhrami di Batavia sampai pertengahan abad ke-19 adalah kelompok sayid atau juga disebut sebagai Alawiyin, dimana mereka merepresentasikan dirinya sebagai keturunan nabi (ahlul bait) dengan otoritas keagamaan yang kuat. Dalam tradisi Alawiyin terdapat konsep kafa'ah pernikahan, dimana seorang perempuan dari kalangan sayid (bergelar syarifah) harus menikah dengan lelaki sayid, sementara sayid dapat menikah dengan syarifah dan non-syarifah. Hal itu dilakukan untuk menjaga kemurnian nasab patrilineal mereka sebagai keturunan nabi. Oleh karena imigran sayid Hadhrami tidak membawa para syarifahnya dari Hadhramaut, maka kebanyakan mereka kemudian menikahi perempuan syarifah keturunan Arab (muwalad) yang telah lahir dari keturunan lelaki Hadhrami dan perempuan pribumi, maupun menikah dengan perempuan pribumi. Pandangan inilah yang menyebabkan komunitas Hadhrami terutama dari kalangan para sayid melakukan pola asimilasi dengan perkawinan uxorilocal atau matrilokalitas. ${ }^{12}$ Dengan model sosialisasi pernikahan tersebut, maka kebanyakan keturunan Hadhrami hidup dalam budaya lingkungan ibunya yang pribumi.

Sosialisasi lainnya yang terpenting adalah melalui aspek keagamaan di Batavia. Selain menganggap diri mereka sebagai keturunan Nabi yang memiliki otoritas keagamaan yang kuat, mereka juga berpendapat bahwa negeri asalnya yaitu Hadhramaut adalah "negeri pembina ilmu dan kepercayaan”. Mayoritas imigran Hadhrami terutama yang berada di Batavia pada umumnya berasal dari Lembah Syibam dan Tarim yang merupakan pusat keilmuan Islam di Hadhramaut (Berg, 1989: 56-7,79). Dengan dasar tersebut di atas, maka mereka merasa berhak untuk melakukan sosialisasi keagamaan yang kemudian diterima dengan mudah oleh masyarakat muslim di Batavia (Berg, 2000: xxxii). Metode dan pengajaran keagamaan yang bersifat tradisional dengan dasar pada pemahaman dan penerjemahan tradisi keagamaan nabi secara tekstual, seperti pembelajaran Al-Qur'an, hadis, hukum pokok Islam, pembacaan maulid, dan ratib (wirid rutin) serta sejarah kehidupan Nabi dan sahabat, semuanya dapat diterima dengan mudah oleh masyarakat muslim di Batavia (Ibrahim, 2011: 12). Oleh karena itulah, maka secara tidak langsung individu dan kolektif Hadhrami kemudian mendapat ruang penting keagamaan dalam kehidupan sosial keagamaan masyarakat muslim di Batavia. Hal tersebut terlihat dalam penelitian Abdul Aziz (2002: 39-40) yang menyebutkan bahwa:

12) Perkawinan uxorilocal atau matrilokalitas adalah sebuah sistem sosial dimana setalah perkawinan terjadi maka anak akan terus hidup bersama dengan ibunya, sehingga anak tersebut kemudian membentuk kekerabatan erat dengan keluarga dari pihak ibu (Berg, 2000: xxxv). 
“...sejak abad ke-19 orang Arab diakui dengan penuh hormat oleh orang Betawi sebagai bangsa yang paling mulia dan kuat beribadah...".

Dalam sumber lain seperti Blackburn (2011) yang mengutip karya terjemahan Pijper (1984) ${ }^{13}$ juga menunjukan bahwa masyarakat muslim di Batavia sangat simpati dengan sosialisasi keagamaan para agamawan Hadhrami. Walaupun peristiwa itu terjadi pada awal abad ke-20 dan tidak terjadi pada abad ke-19, namun catatan Blackburn tersebut dapat menjadi gambaran penting bahwa komunitas Hadhrami secara turun temurun telah melakukan usaha sosialisasi keagamaan secara turun temurun sejak akhir abad ke-18 di Batavia. Kutipan Blackburn (2011: 63) yang dimaksud adalah seperti berikut:

"Di samping kehidupan kampung, ada pula hiburan jalanan yang dapat dinikmati semua orang, serta berbagai festival yang hampir tidak berubah seperti pada masa lalu. Perayaan besar keagamaan menarik massa dalam jumlah besar. Hari raya Islam seperti lebaran, Isra Mi'raj dan Maulid menarik perhatian ribuan orang untuk ke masjid-masjid besar, terutama bila terdapat penceramah favorit, orang Batavia dan sekitarnya mendatangi masjid Pekojan untuk mendengar ceramah Isra Mi'raj dari Sayid 'Ali bin 'Abd-al'Rahman al-Habashi”.

\section{Pembentukan Identitas dalam Masyarakat Kolonial: Budaya Kaum Hadhrami di Batavia}

Untuk melihat kebudayaan komunitas Hadhrami di Batavia, khususnya sampai akhir abad ke-19 maka dapat dilihat dari empat aspek sosial-kebudayaan ${ }^{14}$, seperti: Pertama, yaitu aspek fisik atau budaya material yang melekat pada komunitas Hadhrami di Batavia. Beberapa diantaranya adalah bangunan rumah tembok yang dibangun tingkat dengan balkon tertutup dengan jendela tidak menghadap ke jalan. Hal itu ditujukan untuk memperlihatkan status sosial mereka dibandingkan dengan penduduk pribumi yang pada umumnya merupakan lapisan sosial bawah di Batavia. Secara umum, bangunan tersebut juga sangat berbeda dengan yang ada di Hadhramaut. Dengan ciri bangunan rumah seperti itu, maka sebagian masyarakat Hadhrami di Batavia seperti di Pekojan dapat menjaga bagian tubuh perempuan (aurat) mereka yang dilarang dilihat oleh lelaki non-keluarganya sesuai ajaran agama Islam (aurat), maupun juga tidak terganggu dengan lingkungan yang kumuh dan kotor disekitarnya.

13) Kutipan Blackburn ini diambil dari karya Pijper berjudul "Studien Over de Gechiedenis van de Islam in Indonesia, 1900-1950” yang diterbitkan oleh E.J. Brill Leiden pada tahun 1977. Karya Pijper tersebut kemudian diterjemahkan dalam bahasa Indonesia pada tahun 1984.

14) Empat unsur penting dari abstrak menuju kongkret diantaranya adalah aspek fisik (material), perilaku, kebahasaan, dan gagasan (Ahimsa-Putra, 2013: 9). 


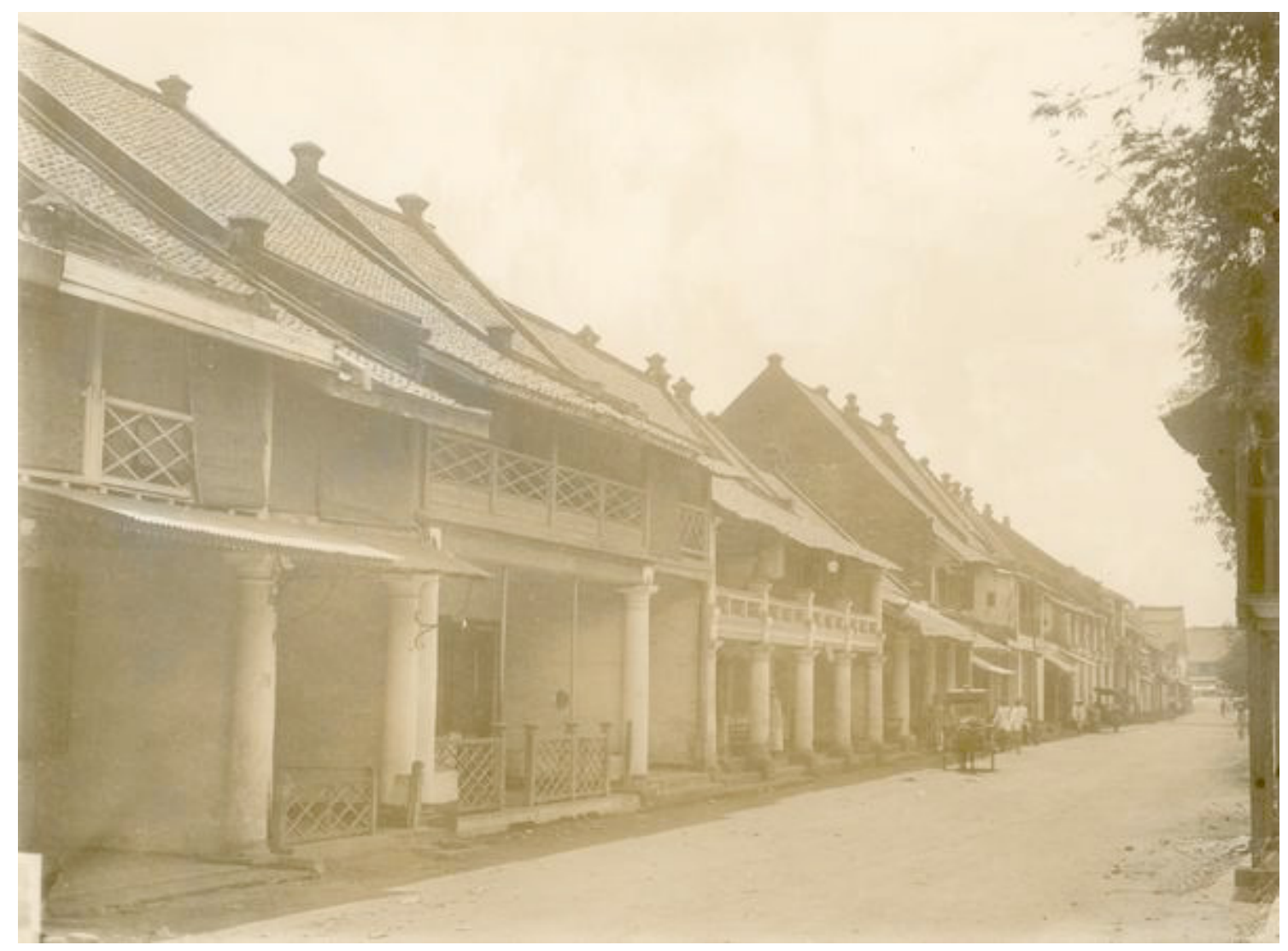

Figur 2. Pemukiman Hadhrami di Pekojan, Batavia (Sumber: KITLV A675 kode Koleksi 88584)

Bentuk bangunan kolonial yang dimiliki oleh orang Hadhrami tersebut juga menunjukkan makna pembeda atas identitasnya dengan masyarakat pribumi yang enggan membangun rumah tembok seperti orang Arab. Hal itu disebutkan dalam catatan perjalanan Dr. Strehler yang mengunjungi Batavia pada tahun 1828 dimana ia melihat bahwa pada umumnya masyarakat pribumi enggan membangun rumah tembok seperti orang Arab. ${ }^{15}$

Dalam lingkungan rumah orang Hadhrami juga dapat ditemukan berbagai barang yang belum tentu dimiliki oleh etnis lainnya, seperti: pipa, kurma, minyak samin, sari bunga mawar dan daging kambing. Untuk pakaian sehari-hari, anak perempuan dan istri orang Hadhrami sudah terbiasa mengenakan pakaian perempuan pribumi (kebaya), terkecuali yang menjadi pembeda adalah mereka mengenakan kerudung dan ini tidak dilakukan oleh perempuan pribumi di Batavia. Salah satu yang masih dipertahankan oleh lelaki Hadhrami di Batavia pada akhir abad ke-19 adalah tidak pernah memakai destar sebagai pengganti serban (Berg, 1989: 122). Pada kalangan Hadhrami

15) Dr. Strehler merupakan warga kebangsaan Jerman yang bekerja sebagai tenaga medis di kapal Belanda yang berlayar ke Hindia Belanda. Strehler bersama rombongan kapal Kapten Woodes Rogers tiba di Batavia pada tanggal 18 Februari 1828 (Amran, 2012: 54). 
yang terhormat, mereka sering sekali mengenakan pantalon dengan sepatu dan kaos kaki seperti orang Eropa daripada sarung yang panjang (futah). Pada masa tersebut, banyak orang Hadhrami yang tidak suka memakai pakaian nasional karena sering menjadi olok-olokan anak-anak. ${ }^{16}$

Kedua adalah aspek perilaku, dimana orang-orang Hadhrami tidak terbiasa bekerja kasar dan berat, sehingga banyak dari mereka yang menjadi pedagang grosiran yang dijajakan oleh penjaja pribumi. Dalam catatan Berg (1989) disebutkan bahwa pedagang Hadhrami hanya memiliki sedikitnya 30-an toko di Batavia khususnya di Pekojan pada tahun 1884. Bentuk usaha perdagangan ini menurut Berg menjadi ciri khas utama perdagangan Hadhrami di Batavia pada akhir abad ke-19 ketika pedagang Hadhrami di luar Batavia lebih mengutamakan kepemilikan toko (Berg, 1989: 73). Selain perdagangan grosir dan toko, terdapat beberapa orang Hadhrami yang menjadi penulis, ${ }^{17}$ pemilik industri kecil, pemilik dan buruh pelayaran, perdagangan antar pulau, penasihat maupun agen mediator pemerintah kolonial khususnya dari kalangan para sayid.

Ketiga adalah aspek kebahasaan dimana komunitas Hadhrami sangat piawai dalam mempelajari bahasa lokal masyarakat Batavia. Oleh karena itu dalam kehidupan komunitas Hadhrami telah menggunakan bahasa Melayu dalam kehidupan sehari-hari. Beberapa hal yang berbeda adalah adanya beberapa logat bahasa tertentu yang jika didengar oleh selain komunitas mereka dapat menjadi indikasi bahwa mereka adalah orang Hadhrami atau keturunnanya. Pada umumnya mereka sangat suka menggunakan syair-syair untuk pujian, bahkan juga terkadang untuk permusuhan yang dinyatakan dengan kalimat sumpah serapah (Berg, 1989: 124-5). Syair bagi mereka juga dinyanyikan dalam bentuk qasidah untuk lagu pujian ketika digelar acara resmi seperti pernikahan dan peringatan kelahiran Nabi (maulid) (Shahabuddin,1944: 25-6, 57).

Keempat, adalah aspek pengetahuan ataupun gagasan kolektif yang terdapat pada komunitas Hadhrami. Beberapa gagasan kolektif tersebut yang paling utama adalah perasaan kesadaran kolektif bahwa mereka adalah penguasa otoritas keagamaan di Batavia. Dengan hal itu maka mereka

16) Pakaian para sayid dan golongan menengah di kalangan Hadhrami mengalami penyesuaian, seperti penggantian jubah dengan kemeja panjang putih (qamis) sampai mata kaki. Di bawah jubah dikenakan celana dalam (sirwal) bukan sarung (futah), namun penggunaan rompi (badan) masih lazim dikenakan. Baju yang panjangnya sampai mata kaki (jubbah) dan baju penghangat (sudairiah) hanya dikenakan dikalangan orang tua, selendang dada (radi) juga jarang digunakan dan beralih pada saputangan (rumal) yang dikenakan dibahunya untuk mengikat kunci. Serban digunakan dalam konteks acara resmi sedangkan kopiah dikenakan jika dalam keadaan santai dengan rambut yang selalu dicukur pendek (Berg, 1989: 123-4).

17) Khusus di Batavia, tokoh Hadhrami yang menduduki jabatan penasihat kehormatan Bangsa Arab adalah Sayid Uthman bin Yahya pada tahun 1899-1913 (ZainiLajoubert, 2008: 12). 
kemudian mendirikan majelis dan pusat dakwah seperti masjid dan langgar. Dalam kegiatan pengajaran majelis keagamaan, mereka juga mengadakannya di salah satu lantai dasar Langgar Tinggi di Pekojan, namun jika mereka melakukan salat Jumat maka dilaksanakan di masjid besar di Pekojan. Di Pekojan juga terdapat masjid yang agak besar yaitu masjid Zawiyah, namun mereka tetap sepakat lebih memilih masjid Pekojan untuk solat Jumat dengan alasan bangunan yang lebih luas dan lebih awal keberadaanya (Berg, 1989: 73). Selain itu, hal yang terpenting lainnya yang menjadi gagasan kolektif adalah kesadaran -kesayidan-yang sejak kecil ditanamkan pada anak-anak mereka sebagai kelompok yang tertinggi dibandingkan Hadhrami non-sayid (syekh) dan pribumi. Kesadaran tersebut juga sesuai dengan konsekwensinya yaitu tetap mempertahankan tradisi Alawiyin yaitu menggunakan gelar sayid, nikah kafa'ah, dan praktik cium tangan (taqbil). Kesadaran kolektif sebagai sayid juga mempengaruhi mereka untuk enggan mengerjakan pekerjaan kasar sebagai buruh, petani dan tetap bertahan dalam usaha perdagangan dan usaha pelayaran ataupun kelas terendah dalam pekerjaan mereka yaitu pedagang keliling dan eceran (Berg, 1989: 122-3, 2000: xxxiv). Abdul Aziz (2002: 39) menyatakan bahwa kehidupan kaum Hadhrami sebagian besar telah terbentuk dalam simbol penting keagamaan di Batavia, sehingga secara tidak langsung mereka berusaha keras secara kolektif untuk mempertahankan prestisnya tersebut.

\section{Pergeseran Sosial: Dari Pekojan ke Tanah Abang}

Sampai pertengahan abad ke-19, komunitas Arab telah membentuk kolektif mereka sesuai yang disebut oleh pemerintah kolonial sebagai "koloni Arab". Sejak tahun 1844, koloni Hadhrami di Batavia telah memiliki Kapten Arab bernama Syekh Muhammad Hasan Babeheir yang kemudian diteruskan oleh Sayid Muhammad bin Abu Bakar Al-Aidid. ${ }^{18}$ Kapten Arab tersebut dibantu oleh seorang pejabat yang berpangkat adj. kapten Arab seperti yang pernah dijabat oleh Syekh Abubakar bin Muhamad bin Abdulah Bamoesbah (Bintang Timor ,17 Februari 1877). Mereka diangkat oleh pemerintah kolonial untuk mengurusi berbagai hal tentang hubungan pemerintah dengan masyarakat Hadhrami.

Sampai dengan pertengahan abad ke-19, secara bertahap pusat pemerintah dan pemukiman Eropa telah bergeser dari kota Batavia tua menuju Batavia yang baru di Weltevreden. Pengerjaan kawasan Tanah Abang

18) Syekh Muhamad Hasan Babeheir menjabat Kapten Arab sejak tahun 1844-an dan kemduian diteruskan oleh Sayid Muhammad bin Abu Bakar Al-Aidid yang pernah berjasa bagi pemerintah, khususnya dalam Perang Aceh. Ia kemudian mendapat gelar kehormatan Mayor pada tahun 1877 dan gelar pangeran (sebagai gelar kebangsawanan pribumi tertinggi) pada tahun 1879. Jabatan Kapten Arab selanjutnya adalah Syekh Umar Mangusy yang menjabat pada masa awal abad ke-20 di Batavia (Berg, 1989: 117 ; Gobee dan Adrianse, 1994: 1637-8, 1674). 
dan Weltevreden sendiri telah dimulai sejak tahun 1753 sampai akhirnya Gubernur Jenderal Daendles memulai membangun Weltevreden pada tahun 1810 (Blackburn, 2012: 59, 62). Dinamika tersebut juga terjadi pada sebagian dari komunitas Hadhrami di Batavia yang juga mulai meninggalkan kampung Pekojan menuju daerah sekitar Weltevreden yang lebih nyaman. Alasan utama pergeseran tersebut dikarenakan lingkungan pemukiman Pekojan yang semakin padat dan kumuh karena meningkatnya jumlah imigran Hadhrami yang datang ke Pekojan pada paruh kedua abad ke-19 kerena kemudahan transportasi laut pasca dibukanya terusan Suez 1869. Selain itu, peraturan sistem perkampungan Arab (wijkenstelsel) ${ }^{19}$ yang berlaku sejak tahun 1866 dengan penggunaan kartu jalan (passenstelsel) atau surat permisi di pelabuhan telah membuat kesulitan banyak orang Hadhrami dalam proses sosialisasi dan interaksinya. Selain alasan tersebut, terdapat juga beberapa hal yang mempengaruhi pergeseran sebagian komunitas Hadhrami yaitu seperti menurunnya usaha pelayaran Hadhrami ${ }^{20}$ pada akhir abad ke-19. Hal itu terjadi karena kebijakan pemerintah kolonial mendirikan usaha pelayaran yaitu Koninklijke Paketvaart Maaatschappij (KPM) pada tahun 1888 yang mengalahkan usaha pelayaran dan biaya perdagangan antar pulau milik Hadhrami di Batavia. Oleh karena itu, maka banyak pengusaha Hadhrami di Batavia mengalihkan usaha perekonomiannya di tanah partikelir pedalaman Jakarta yang mulai berkembang setelah tahun 1870-an. Banyak dari mereka yang kemudian menjadi pengusaha properti sampai awal abad ke-20.

Salah satu bagian dari komunitas Hadhrami yang pindah dari Pekojan menuju kawasan Tanah Abang adalah keluarga Sayid Abdulah bin Alwi bin Abdulah al-Athas yang kemudian berhasil menjadi pedagang kaya. ${ }^{21}$ Pada akhir abad ke 19, keluarga al-Athas merupakan kelompok elit Hadhrami di Batavia yang menjadi penguasa properti terbesar. Blackburn (2011: 87) menyatakan bahwa perpindahan Sayid Abdulah bin Alwi al-Athas ini menjadi

19) Faktor yang menyebabkan pembentukan kampung etnis adalah peningkatan jumlah migrasi kaum Hadhrami yang meningkat serta campur baur golongan Timur Asing dengan pribumi (Gobee dan Adriaanse, 1994: 1649-1677 ; Berg, 2000: xl ; Bintang Betawi, 14 Januari 1904).

20) Pada dunia usaha pelayaran, Komunitas Hadhrami pernah mencapai puncak kejayaannya khususnya pada tahun 1750 -an, dimana pada periode 1774 - 1777 sejumlah $2 \%$ dari jumlah kapten kapal di Pelabuhan Jawa dioperasikan oleh orang Hadhrami. Pengusaha kapal Hadhrami baik dari Batavia, Singapura, Palembang dan Surabaya telah menyediakan kapal angkutan dengan rute Jawa-Palembang-Malaka dengan kapal kapasitas muatan 50 ton, dimana pada tahun 1820 meningkat menjadi $22 \%$ dan pada tahun 1850 meningkat menjadi 50\%. Oleh karena itu maka pemerintah kemudian mendirikan Koninklijke Paketvaart Maaatschappij (KPM) pada tahun 1888 yang secara perlahan mengalahkan dominasi usaha pelayaran pengusaha Hadhrami (Berg, 2000: xxxiv -xxxv).

21) Wilayah Tanah Abang pada awalnya adalah milik Justinus Vinck yang pada tahun 1735 diizinkan oleh VOC untuk pendirian pasar dan toko. Rumah Sayid Abdulah bin Alwi al-Athas yang dimaksudkan Edrus Alwi Al Mashoer berada di Djati Petamburan dekat dengan Tanah Abang dimana rumah tersebut sekarang menjadi museum tekstil (AlMasjhoer, t.t: 64). 
awal perpindahan kaum Hadhrami dari Pekojan ke daerah selatan Batavia. Menjelang akhir abad ke-19 sampai dekade awal abad ke-20, banyak kalangan Hadhrami yang memiliki modal cukup juga bergeser ke daerah pengembangan tanah partikelir di selatan Batavia lama. Daerah yang dituju adalah seperti Tanah Abang, Petamburan, dan Krukut. Dari ketiga daerah tersebut mereka kemudian menyebar ke sekitar daerah Sawah Besar, Jatinegara dan Tanah Tinggi serta Cawang. Tidak semua orang Hadhrami berprofesi sebagai pengusaha penyewaan lahan dan rumah di daerah barunya, namun juga mengembangkan usaha baru yaitu menjadi pedagang perantara di pinggiran kota. Usaha tersebut dipilih karena hal itu juga yang dilakukan oleh pedagang Tionghoa ketika tanah partikelir menyediakan hasil pertanian dan perkebunan dan tentunya pembukaan pemukiman-pemukiman baru. Sebagian kalangan Hadhrami juga melakukan perdagangan batik, persewaan rumah untuk kontrak tahunan dan peminjaman uang (Lohanda, 1994: 23). Pada akhir abad ke-19, khususnya di kalangan para sayid telah banyak keturunan campuran (muwalad) yang membentuk banyak perubahan identitas baru yang berbeda dengan generasi awal mereka di Pekojan. Sementara di kalangan imigran baru non-sayid (syekh) yang datang pada akhir abad ke-19 dan banyak tinggal di Pekojan juga mengalami perubahan identitas baru yang berbeda dengan tanah asalnya yaitu Hadhramaut.

\section{Permasalahan Sosial, Modernitas dan Nasionalisme}

Tersebarnya pemukiman Hadhrami diberbagai sudut kawasan di kota Batavia menjadikan etnis Hadhrami mulai berbaur dengan kehidupan heterogen yang terjadi di Batavia. Pada masa perkembangan tanah partikelir di pinggiran Batavia berbagai permasalahan sosial kota mulai bermunculan diantaranya adalah kriminalitas dan kerusuhan. Menurut Blackburn (2011) dengan didominasinya kawasan Batavia menjadi tanah partikelir maka mengakibatkan maraknya praktek renternir yang dilakukan oleh banyak kalangan ekonomi atas, terutama dilakukan oleh para tuan tanah partikelir tersebut. Tanah-tanah pribadi di Batavia dan sekitarnya terkenal sebagai daerah tak berhukum dan sering terjadi pencurian. Rawannya pencurian tersebut sampai menjadi topik berita di harian Pemberita Betawi dengan istilah "banjak maling" (Pemberita Betawi, 31 Januari 1913). Keributan juga sering terjadi di sekitar kota Batavia, walaupun pemerintah tidak menganggapi itu sebagai sebuah ancaman (Blackburn, 2011: 95). Berbagai kasus tersebut di atas diantaranya adalah kasus keributan dan perkelahian antar etnis Arab dan Tionghoa yang terjadi di Kampung Arab Sentiong Asem Reges (Bintang Timor, 24 November 1877), kasus penipuan yang melibatkan orang Arab seperti kasus Syekh Awab bin Ahmad Bakada Pekojan yang ditangkap oleh polisi dan kasus pencurian oleh seorang pribumi terhadap rumah orang Arab bernama Syekh Hasan Masri (Pemberita Betawi, 3 Mei 1901; Bintang Timor, 12 Desember 1877). 
Transformasi sosial budaya merupakan proses perubahan struktur, sistem sosial, dan budaya atau diartikan sebagai proses perubahan atau pembaharuan struktur sosial, sedang di pihak lain mengandung makna proses perubahan nilai (Soemardjan, 1981: 3-4). Transformasi ini juga terjadi pada komunitas Hadhrami pada masa akhir abad ke-19 dan awal abad ke-20. Kebijakan pemerintah kolonial tentang sistem liberal pasca tahun 1870-an telah berpengaruh pada perubahan rupa identitas Hadhrami yang baru, seperti:

\section{Aspek Fisik atau Budaya Material}

Gambaran yang terjadi dalam bangunan rumah komunitas Hadhrami di Batavia hampir seluruhnya dibangun dengan gaya rumah Eropa yang mewah ${ }^{22}$ dilengkapi dengan perangkat rumah modern seperti meja, kursi, dan lemari besar seperti yang dimiliki oleh orang Eropa, dimana hal itu jarang dimiliki oleh masyarakat pribumi di Batavia. Salah satu contohnya adalah kepemilikan pigura besar dan barang étagère (rak) yang diiklankan oleh seorang Arab di dalam surat kabar Harian Bintang Timor tahun 1877 (Bintang Timor, 6 juni 1877). Bentuk pakaian merupakan bagian penting tentang identitas etnis di Batavia pada akhir abad ke-19 (Bintang Timor, 22 Desember 1883). Pakaian kaum wanita keturunan Hadhrami tetap memakai kebaya hanya ditambah dengan kerudung, walaupun terdapat dikalangan elit atas seperti Siti Noor Binh Benbarah Baloeel yang sudah mengenakan baju perempuan seperti perempuan Eropa pada tahun 1922 (Lohanda, 1994: 39). Untuk pakaian para lelaki di kalangan elit Hadhrami juga telah mengalami perubahan seperti dengan model tiga bentuk jenis pakaian lengkap, yaitu : rantai arloji pada rompi, kemeja putih dan dasi kupu-kupu yang betul-betul menyerupai pakaian Eropa. Dalam sebuah foto berjudul "De School” dalam karya Ednan Al Mecky (t.t : 5) diperlihatkan tentang penampilan seorang pengajar dan pengurus sekolah yang mengenakan pakaian haji, jas tutup (sebagai pakaian tropis bangsa Eropa), tutup kepala peci yang sederhana dan ada yang memakai sorban yang megah. Perubahan identitas tentang pakaian juga disebabkan oleh pengaruh interaksi mereka dengan pejabat konsulat Turki di Batavia maupun Singapura yang semakin menyemarakkan pemakaian pemakaian peci merah Turki (terbus) dan penggunaan istilah Arabier, walaupun gelar sebutan tuan atau sayid masih berlaku (Algadri, 1996: 30-1). Tarbusy juga disebut fez, di dalam foto yang diungkapkan oleh Al-Mecky (t.t) tersebut terlihat bahwa para siswa Alatas School telah mengenakan celana pendek, kaos kaki, dan jas tutup yang mirip dengan pakaian seragam sekolah anak-anak Eropa dan bukan mengenakan sarung atau jubah lagi (Bintang Timor, 17 Desember 1883; Kaoem Moeda , 20 Januari 1914 ; Al Mecky, t.t: 5).

Identitas yang dijadikan peraturan oleh pemerintah kolonial seperti pemakaian serban untuk etnis Arab, kucir di kepala bagi etnis Tionghoa

22) Penampilan Siti Noor Bin Benbarah Baloeel yang merupakan istri dari Sayid Ismail Alatas di Batavia pada tahun 1922 dapat dilihat dalam foto koleksi KITLV no. 6588. 


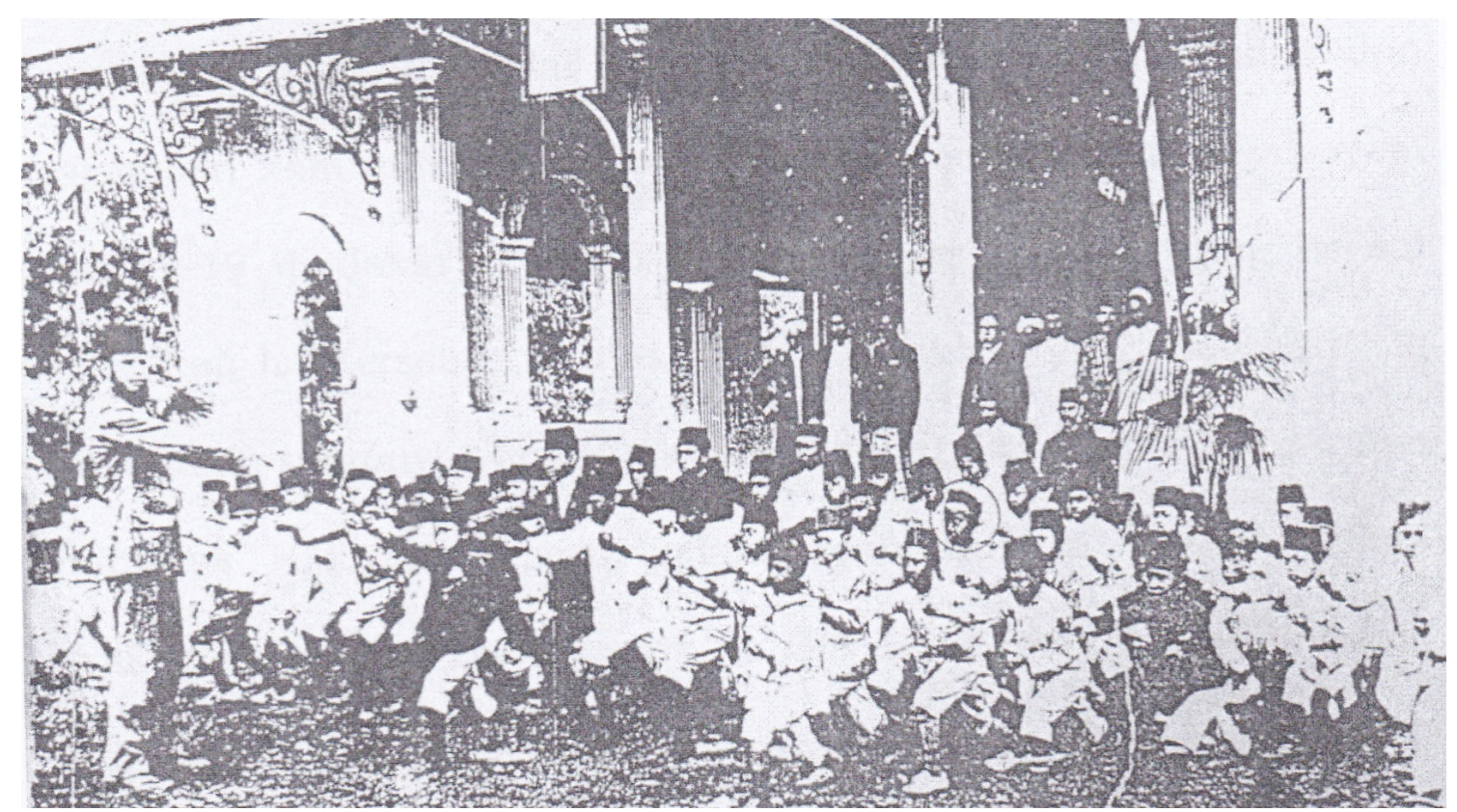

Figur 3. Guru Arab bernama Al-Hasyimi di Sekolah Arab Batavia tahun 1913 (sumber: Abou Guecha: Politic Satirich Blad, t,t, hlm. 1).

dan kain pinggang bagi kaum pribumi secara perlahan mulai berganti menjadi pemakaian model Eropa pada awal abad ke-20 di Batavia (Gobee dan Adrianse, 1994:1707). Dalam masalah barang-barang di rumah tangga, kalangan Hadhrami pasti masih memiliki pipa tembakau hogah atau nargileh, karpet permadani, bantal dan guling tebal yang besar, dan tempat pembakaran dupa atau menyan Arab serta talam lebar untuk jamuan kebuli (Al-Mecky, t.t: 15). Hal tersebut tetap masih dipertahankan walaupun disisi lain telah hadir perkakas rumah tanggal lainnya yang lebih modern seperti meja, kursi dan lainya. Dari sisi bangunan, kalangan Hadhrami mulai mengembangkan bangunan-bangunan penting bergaya Eropa pada rumah tinggal mereka. Beberapa masjid juga telah dibangun dengan model bangunan Eropa, kecuali pada bagian menara yang masih menggunakan model masjid di Hadhramaut.

Pada awal abad ke-20, komunitas Hadhrami juga telah membangun sekolah Islam (madrasah) seperti madrasah Jamiat Khair di Pekojan yang berdiri pada tahun 1905. Dalam perkembanganya, sekolah di Pekojan tersebut kemudian pindah ke jalan Karet Weg, Tanah Abang dan kembali pindah di area baru di sekitar Tanah Abang (Pemberita Betawi, 12-14 Maret 1913). Prasarana lainnya yang didirikan oleh kaum Hadhrami adalah pembangunan asrama pelajar (internaat) di jalan Karet no. 72 yang mulai dibuka pada tanggal 15 Mei 1924, disusul pembangunan maderasah ibtidaiyah putri (setingkat sekolah dasar) di Kebon Melati, Tanah Abang pada tanggal 26 Maret 1929 (Al-Masjhoer, t.t: 36). Semua bentuk bangunan sekolahan tersebut telah bercirikan bangunan gedung sekolah Eropa, tidak seperti maderasah yang berada di Hadhramaut yang lazim disebut sebagai ribath. 


\section{Aspek Perilaku atau Budaya Perilaku}

Dalam perilaku sehari-hari banyak kalangan Hadhrami kelas menengah ke bawah yang masih menggunakan sungai seperti Ciliwung untuk kebutuhan mandi dan mencuci (Bintang Timor, 30 Mei 1877), walaupun mereka sudah pindah dari Pekojan. Banyak juga orang Hadhrami yang belum memiliki rumah sendiri dan masih mengontrak rumah di Batavia. Hal itu dalam kalangan Hadhrami adalah hal yang umum dan terjadi di berbagai kota-kota besar di pulau Jawa pada umumnya (Pemberita Betawi, 24 Mei 1913). Kalangan elit komunitas Hadhrami di Batavia rata-rata didominasi oleh para tuantuan tanah ${ }^{23}$ yang membuat afiliasi dengan para konsul Jenderal Turki di Batavia dalam kepentingan penyamaan status kewarganegaraan dengan Eropa dan modernisasi pendidikan Islam. Gerakan ini juga sudah dimulai oleh kalangan Hadhrami di Singapura dan pengaruhnya merembet pada kalangan borjuis Hadhrami di Batavia (Berg, 2000: xliii). Salah satu tokoh terkemuka dalam usaha tersebut adalah Sayid Muhamad bin Abdurahman Syahab (AlMasjhoer, t.t: 20; Mandal, 2002: 176). Banyak dari kalangan Hadhrami secara tegas menolak menyekolahkan anaknya di sekolahan Kristen Belanda seperti sekolah dasar untuk pribumi ningrat yang berdiri pada tahun 1906 (Algadri, 1984: 138).

Pada masa ini asimilasi pada kalangan Hadhrami di Batavia tidak lagi ditentukan melalui perkawinan dengan anak tokoh pribumi, namun justru sesama keluarga keturunan Hadhrami dengan jalinan pernikahan antar keluarga dan kota. ${ }^{24}$ Mereka juga menuntut kepada pemerintah kolonial bahwa seharusnya yang menikahkan orang Hadhrami adalah pengulu Arab, bukan pengulu pribumi. Berbagai hal tersebut terjadi karena posisi sosial mereka yang telah kuat di Batavia pada akhir abad ke-19 dan awal abad ke-20.

23) Para tuan tanah Hadhrami di Batavia yang terkenal, seperti Sayid Ali bin Syahab (tuan tanah Menteng), Abdulkadir Alaidrus, Sahl bin Sahl, Abdulah bin Alwi Alatas, Muhamad bin Abdurahman Salabiyah mereka bekerjasama dengan konsul Jenderal Turki Kiamil Bey yang sejak tahun 1898 menjanjikan akan menekan pemerintah kolonial Hindia Belanda untuk menyamakan status orang Hadhrami dengan orang Eropa di Hindia Belanda. Kerjasama tersebut telah memberikan harapan baru kepada komunitas Hadhrami akan kemajuan kehidupan mereka terutama dalam status etnisitas yang berpengaruh pada bidang perekonomian dan politik maupun pada aspek pendidikan dan keagamaan (Algadri, 1984:136 ; Al-Masjhoer, t.t.: 18).

24) Tentang pernikahan kalangan Hadhrami telah disebutkan bahwa dalam kelompok sayid terdapat tradisi penikahan kafa'ah untuk mempertahankan gelar sayid dari jalur ayahnya. Oleh karena itu mereka cenderung menikah dengan sesama kalangan keturunan Hadhrami. Di Batavia, pada akhir abad ke-19 pernikahan sering terjadi antara keluarga para sayid seperti klan Al-Atas dengan As-Syahab, maupun dengan perempuan dari kelompok syekh. Pernikahan antar klan dalam komunitas Hadhrami juga dapat terjadi di antara keluarga Hadhrami di Batavia dengan yang di luar Batavia. Pernikahan-pernikahan tersebut disebabkan oleh jaringan perekonomian dan keagamaan sesama Arab yang primordialis. Tentang keutamaan menikahi perempuan Arab dan keturunannya dapat di lihat pada bin Yahya (1924:4) dan bin Yahya (t.t.:4). Untuk permohonan pengulu Arab dalam pernikahan Hadhrami lihat dalam Perihal Kumpul Uang bikin Sinuman, Plano 53 FI. 
Selain itu, banyak kalangan Hadhrami yang tidak lagi menikahi putri para bangsawan lokal karena posisi mereka telah tergeser kepada para pejabat lokal kolonial atau pegawai kolonial yang pada masa tersebut juga telah disebut sebagai priyayi.

\section{Aspek Kebahasaan}

Perihal bahasa pada generasi keturunan Hadhrami di Nusantara khususnya pada awal abad ke-20, mereka sudah banyak yang memakai bahasa pribumi. Hal itu terjadi juga di Batavia dimana dalam perkembangannya terlihat ketika telah beredar beberapa surat kabar Arab di Batavia, seperti harian Bir Hoed yang dikeluarkan oleh Sayid Moehamad bin Agil bin Yahya, mingguan alSomil yang dipimpin oleh Ali bin Abdullah Aseggaf, dan majalah Borobudur Journal Arab dengan redaksi dipimpin oleh M.O Hasyimi (Al-Masjhoer, t.t: 49). Pada elit generasi tua Hadhrami pada awal abad ke 20 tetap berusaha mempertahankan pemakaian bahasa Arab untuk pergaulanya, namun jarang di antara mereka yang mengajarkan bahasa Arab kepada anaknya dan cenderung mengirim anak-anak mereka untuk belajar di sekolah Eropa seperti Hogere Burgerschool (HBS) (al-Mecky, t.t: 16). Dalam Pemberita Betawi dikabarkan bahwa menurunnya penggunaan dam pembelajaran bahasa Arab di Batavia pada tahun 1913 telah memunculkan sebuah pertanyaan dari seorang berinisial A.R.S tentang apakah sekolah bahasa Arab di Pekojan dan Tanah abang atau Sekolah Daja Oepaja dapat menerima siswa perempuan untuk belajar bahasa Arab (Pemberita Betawi, 26 Mei 1913). Seperti Aliran Baroe yang dieditori oleh Bafagih, secara aspek kebahasaan mereka cenderung membentuk identitas mereka bahwa "status Hindia Belanda lebih dipilih sebagai tanah air kelahiran keturunan Arab” (Algadri, 1996: 35).

Kemunculan surat kabar dengan bahasa Arab adalah pembentukan sebuah identitas tersendiri pada awal abad ke-20, dikarenakan surat kabar bahasa Arab merupakan penuntun imaginasi mereka agar selalu sadar diri "sebagai bangsa Arab". (Berg, 2000: xliii). Permasalahan perubahan kebahasaan dalam komunitas Hadhrami juga nampak muncul dalam berbagai acara resmi mereka. Hal itu seperti terlihat pada sebuah undangan mauled yang diadakan oleh Jamaat Khair (Djemaet Geir) yang dimuat dalam surat kabar Pemberita Betawi. Dalam surat undangan itu mereka telah menggunakan bahasa Melayu yang dikombinasikan dengan bahasa Belanda seperti istilah kata Vereeniging (Pemberita Betawi, 13 Januari 1914).

\section{Aspek Pengetahuan ataupun Gagasan Kolektif}

Dalam berbagai sumber penelitian tentang komunitas Hadhrami khususnya pada akhir abad ke-19 ditemukan beberapa catatan penting tentang gagasan kolektif komunitas Hadhrami di Batavia yang terjadi pada tahun 1898. Peristiwa penting tersebut bermula ketika seorang tokoh agama Hadhrami yaitu Sayid Usman bin Abdullah bin Yahya menghendaki berdirinya sebuah 
lembaga pendidikan agama modern untuk anak-anak Hadhrami karena banyaknya sekolah pemerintah yang bermunculan (Al-Masjhoer, t.t: 26). Dapat disebutkan bahwa pada akhir abad ke-19, kemajuan pendidikan pada kalangan Hadhrami telah menjadi orientasi kolektif, walaupun kecenderungan yang muncul lebih pada pendidikan "Istanbul sentris", bukan kepada "Hadhramaut sentris" yang merupakan tanah moyang asal mereka.. Mereka juga mulai menyadari pentingnya mempunyai organisasi komunitas Arab dan membentuk "identitas Eropa" agar mendapat kebebasan dalam bertindak di Batavia sesuai hak-hak istimewa warga Eropa. Semuanya telah menjadikan komunitas Hadhrami di Jakarta masuk dalam kehidupan modernitas di Batavia pada awal abad ke-20 (Berg, 2000: xlii).

Penyaluran gagasan kolektif dalam bentuk wadah organisasi kemudian benar-benar terwujud ketika berdirinya "Jamiat Khair" pada tahun 1901 yang diikuti dengan pendirian sekolah berbentuk madrasah pertama kali di Batavia yaitu Madrasah Jamiat Khair pada tahun 1905 di Pekojan. Dengan disahkannya Jamiat Khair oleh Gubernur Jenderal J.B Van Heutsz pada tanggal 17 Juni 1905, maka Jamiat Khair menjadi puncak penting pembentukan identitas kaum Hadhrami di Batavia, bahkan sebagai representasi identitas sosial bagi bangsa keturunan Hadhrami di Hindia Belanda pada awal abad ke-20 (AlMasjhoer, t.t: 15). Selain di Jamiat Khair, para komunitas Hadhrami juga aktif dan terlibat dalam berbagai perkumpulan-perkumpulan sosial seperti Daja Oepaja, dimana Sayid Abdurahman Al Habsyi menjadi sekretaris di dalamnya. Daja Oepaja kemudian menjadi sebuah perkumpulan yang diikuti oleh orang-orang Hadhrami seperti dari Pekojan, Kwitang, Petamburan, Tanah Abang, Penjaringan dan lain sebagainya (Pemberita Betawi, 10 Mei 1913). Kesepakatan bersama dalam gagasan kolektif antara Sarekat Islam, Jamiat Khair, dan pemerintah kolonial terjadi dalam sebuah rapat Sarekat Islam di Batavia sesuai yang diwartakan oleh harian Pemberita Betawi pada tanggal 18 Maret 1913 yang isinya jika Sayid Ali bin Abdurahman Al Habsyi (Daya Oepaja) dan Sayid Mohamad Alaydrus menyambut baik atas kelahiran Sarekat Islam di Batavia. Oleh karena itu kemudian Dr. Rinkes yang hadir mewakili pemerintah kolonial meminta agar sekolah Arab di Tanah Abang yang dipimpin oleh Sayid Muhamad bin Syahab mengadakan pendidikan bahasa Melayu untuk anak-anak Hadhrami (Pemberita Betawi, 18 Maret 1913).

Runtuhnya Istanbul sebagai pusat pan-Islamisme pada awal abad ke-20 kemudian berpengaruh pada orientasi pergerakan Jamiat Khair di Batavia. Pendidikan keagamaan Islam modern tidak lagi menjadi yang paling utama, namun juga mulai dikembangkan berbagai gerakan yang bersifat ekonomi dan politis (Oetoesan Melajoe, 22 Mei 1919; Al-Masjhoer, t.t: 22). Empat aspek kebudayaan di atas menunjukan bahwa identitas komunitas Hadhrami mengalami perubahan-perubahan penting dan menuju dalam satu pembentukan identitas yaitu masyarakat Hadhrami yang modern di Batavia 
pada awal abad ke-20. Perubahan identitas terpenting adalah terjadi pada tanggal 4 Oktober 1934 dimana Persatuan Arab Indonesia (PAI) didirikan oleh A.R. Baswedan sebagai gerakan Islam-Nasionalis yang menyatakan bahwa identitas Hadhrami pada masa tersebut dinyatakan dengan dasar "bahwa Indonesia (Hindia Belanda) adalah tanah air mereka”. Gerakan yang paling awal dilakukan PAI adalah pembenahan identitas sosial Hadhrami yang buruk karena dikenal oleh masyarakat sebagai "renternir" yang kemudian diberantas habis oleh PAI (woekerordonansi). PAI kemudian juga terlibat dalam berbagai pergerakan Nasional pada awal abad ke-20 terutama dalam dukungannya terhadap Gerakan Petisi Soetardjo dan gerakan Indonesia Berparlemen (Hamid, 1996: 37-38).

\section{Kesimpulan}

Dari uraian diatas dapat diketahui bahwa sejak akhir abad ke-18 sampai awal abad ke-19 adalah periode penting bagi para imigran Hadhrami dalam membentuk sebuah komunitas di Batavia, tepatnya di kampung Pekojan. Dalam rangka pembentukan identitas tersebut, beberapa aspek seperti material, bahasa, perilaku dan gagasan kolektif masih memperlihatkan corak kehadhramiannya, walaupun dalam beberapa hal telah menunjukan sedikit corak identitas lokal pribumi di Batavia. Pada periode di atas, imigran Hadhrami di Batavia yang terbanyak jumlahnya adalah para sayid yang melakukan sosialisasi pada bidang perekonomian dan keagamaan. Dalam bidang perekonomian, sosialisasi mereka ditunjukan dengan profesinya sebagai pedagang toko dan grosir, usaha pelayaran, agamawan, maupun pegawai pemerintah kolonial. Pada bidang keagamaan, pada umumnya kalangan sayid lebih menunjukan sosialisasi keagamaan dengan pembangunan masjid dan majelis pengajaran keagaman sebagai simbol penting keagamaan untuk memperkuat legitimasi mereka sebagai keturunan nabi dan pemegang otoritas keagamaan sampai awal abad ke-20.

Dari pertengahan abad ke-19 sampai akhir abad ke-19, berbagai perubahan penting terjadi dalam komunitas Hadhrami di Batavia, seperti semakin banyaknya jumlah imigran Hadhrami terutama dari kalangan nonsayid (syekh) karena kemudahan transportasi laut pada akhir abad ke-19 yang menyebabkan padatnya pemukiman Hadhrami di Pekojan. Pada akhir abad ke-19, perekonomian komunitas Hadhrami dari sektor pelayaran dan perdagangan antar pulau menurun karena pengoperasian pelayaran pemerintah yaitu KPM pada tahun 1888. Di sisi lain, perkembangan usaha di tanah partikelir di pedalaman Batavia juga telah meningkat. Berbagai hal tersebut kemudian mempengaruhi sebagian besar komunitas Hadhrami untuk mengalihkan pemukiman dan kegiatan perekonomian mereka di pedalaman Jakarta pada akhir abad ke-19. Hal tersebut tentu menimbulkan perubahan identitas sosial yang baru, dimana hampir pada semua aspek sosial- 
budaya seperti material, bahasa, perilaku dan gagasan kolektif cenderung memperlihatkan ciri khas modernitas pada masyarakat kolonial di Batavia sampai awal abad ke-20.

Pembentukan identitas sosial Hadhrami pada awal abad ke-20 lebih terlihat sebagai hasil dari bentuk transformasi kolektif, dimana dalam satu sisi mereka masih mempertahankan status kearabanya, namun di sisi lain berusaha mengadopsi berbagai bentuk material, bahasa, perilaku dan gagasan kolektif yang berkembang di masyarakat kolonial Batavia. Pada awal abad ke-20, komunitas Hadhrami kemudian lebih akrab dipanggil dengan istilah "keturunan Arab" yang terbagi menjadi dua bagian dalam gagasan kolektifnya, yaitu yang secara sadar tetap mengakui Hadhramaut sebagai tanah airnya dan cenderung dipimpin oleh kolonial Belanda dan sebagian adalah yang mengakui bahwa "tanah air mereka bukan lagi Hadhramaut, tapi justru Indonesia (Hindia Belanda)" yang mendukung pergerakan nasionalisme dalam mencapai kemerdekaan bangsa Indonesia.

\section{Referensi}

\section{Manuskrip}

Perihal Kumpul Uang bikin Sinuman, Plano 53 FI (Koleksi UB. Leiden)

Shahabuddin, Sayyid Abubakar bin Ali bin Abubakar, Rihlatur Asyfar, 1944 (Koleksi pribadi Ali Shahab, Jakarta)

\section{Foto}

"Huizen aan de Pekodjan, Batavia”, KITLV A675, no 88584.

\section{Surat Kabar}

Bintang Betawi, 14 Januari 1904

Bintang Timor, 22 Desember 1883; 17 Desember 1883; 17 Februari 1877; 30 Mei 1877; 6 juni 1877; 24 November 1877;12 Desember 1877.

Kaoem Moeda , 20 Januari 1914.

Oetoesan Melajoe, 22 Mei 1919.

Pemberita Betawi, 3 Mei 1901; 18 Maret 1913; 12 Maret 1913;13 Maret 1913;14 Maret 1913;10 Mei 1913; 24 Mei 1913; 26 Mei 1913; 13 Januari 1914.

\section{Buku, Jurnal dan Majalah.}

Ahimsa-Putra, Heddy Shri, Budaya Bangsa, Jati Diri dan Integrasi Nasional: Sebuah Teori, Jurnal Sejarah dan Nilai Budaya Jejak Nusantara, edisi perdana, Tahun I, 2013.

Algadri, Mr. Hamid, C. Snouck Hurgronye: Politik Belanda Terhadap Islam dan Keturunan Arab, Jakarta: Penerbit Sinar Harapan, 1984.

, Mr. Hamid Islam dan Keturunan Arab: Dalam Pemberontakan Melawan Belanda, Bandung: Penerbit Mizan, 1996.

Al-Masjhoer, Edrus Alwi, Jamiat Kheir: Sejarah dan Perkembangannya, tk. tp, t.t.

Al Mecky, Ednan , Abu Guecaha, t.k, t.t, t.p.

Amran, Frieda, Batavia: Kisah Kapten Woodes Rogers \& DR. Strehler, Jakarta: Kompas, 2012. 
bin Yahya, Alwi bin Usman, Ini Hikayat Bernama Qomaruzaman, Batavia: Percetakan Sayid Usman, 1924.

bin Yahya, Abdullah bin Usman, Suluh Zaman, Batavia: Percetakan Sayid Usman, t.t.

Aziz, Abdul, Islam dan Masyarakat Betawi, Jakarta: PT. Wacana Logos Wacana Ilmu, 2002.

Berg, LWC. Van den, Hadramaut dan Koloni Arab di Nusantara, Jakarta: INIS, 1989. , Orang Arab di Nusantara, Jakarta: Komunitas Bambu, 2000.

Blackburn, Susan, Jakarta:Sejarah 400 tahun, Jakarta: Masup Jakarta, 2011

Gobee, E. dan Adriaase, C. Nasihat-Nasihat C. Snouck Hurgronje Semasa Kepegawaiannya Kepada Pemerintah Hindia Belanda 1889-1936, Jakarta: INIS, 1994.

Ibrahim, Umar, Thariqah Alawiyyah, Bandung : Penerbit Mizan, 2011.

Jonge, Huub de, “A Divided Minority: The Arab of Batavia," dalam Kees Grijns dan Peter J.M. Nas (eds), Jakarta-Batavia, Leiden: KITLV Press, 2000

Kuntowijoyo, Metodologi Sejarah II, Yogyakarta: Tiara Wacana, 2003.

Mandal, Sumit K, Forging a Modern Arab Identity in Java in the Early Twentieth Century, (ed.) Huub de Jonge and Nico Kaptein, Trancending Borders: Arab, Politics, Trade and Islam in Southeast Asia, Leiden: KITLV, 2002.

Mobini-Kesheh , Nathalie, The Arab periodicals of the Netherlands East Indies, 1914 1942, Bijdragen tot de Taal-, Land- en Volkenkunde 152 (2), 1996, 2, Leiden.

Mona Lohanda, The Kapitan Cina of Batavia : A History of Chinese Estabilishment in Colonial Sosciety, Jakarta: Penerbit Djambatan, 1994.

Raffles, Thomas Stamford, History of Java I, London: Black, Parbury and Allen, 1817. Shahab, Alwi, Maria van Engels: Menantu Habib Kwitang, Jakarta: Republika, 2006

Soemardjan, Selo, Perubahan Sosial di Yogyakarta, Yogyakarta: Gadjahmada Universitypress, 1981.

Zaini-Lajoubert, Monique, Karya Lengkap Abdullah bin Muhammad Al Masri, Jakarta: Komunitas Bambu, 2008. 